\title{
Analysis of apoplastic and symplastic antioxidant system in shallot leaves: Impacts of weak static electric and magnetic field
}

\author{
Turgay Cakmak ${ }^{\mathrm{a}, *}$, Zeynep E. Cakmak ${ }^{\mathrm{b}}$, Rahmi Dumlupinar ${ }^{\mathrm{c}}$, Turgay Tekinay ${ }^{\mathrm{d}}$ \\ a Department of Molecular Biology and Genetics, Faculty of Science, Istanbul Medeniyet University, Istanbul, Turkey \\ ${ }^{\mathrm{b}}$ Department of Biology, Science and Art Faculty, Kırıkkale University, Kırıkkale, Turkey \\ ' Department of Biology, Science Faculty, Atatürk University, Erzurum, Turkey \\ d Laboratory of Sustainable Technologies, Institute of Materials Science and Nanotechnology, Bilkent University, Ankara, Turkey
}

\section{A R T I C L E I N F O}

\section{Article history:}

Received 3 November 2011

Received in revised form 10 March 2012

Accepted 13 March 2012

\section{Keywords:}

Allium ascalonicum

Antioxidant system

Apoplast

Electric field

Magnetic field

ROS

\begin{abstract}
A B S T R A C T
Impacts of electric and magnetic fields (EFs and MFs) on a biological organism vary depending on their application style, time, and intensities. High intensity MF and EF have destructive effects on plants. However, at low intensities, these phenomena are of special interest because of the complexity of plant responses. This study reports the effects of continuous, low-intensity static MF (7 mT) and EF (20 kV/m) on growth and antioxidant status of shallot (Allium ascalonicum L.) leaves, and evaluates whether shifts in antioxidant status of apoplastic and symplastic area help plants to adapt a new environment. Growth was induced by MF but EF applied emerged as a stress factor. Despite a lack of visible symptoms of injury, lipid peroxidation and $\mathrm{H}_{2} \mathrm{O}_{2}$ levels increased in EF applied leaves. Certain symplastic antioxidant enzyme activities and non-enzymatic antioxidant levels increased in response to MF and EF applications. Antioxidant enzymes in the leaf apoplast, by contrast, were found to show different regulation responses to EF and MF. Our results suggest that apoplastic constituents may work as potentially important redox regulators sensing and signaling environmental changes. Static continuous MF and EF at low intensities have distinct impacts on growth and the antioxidant system in plant leaves, and weak MF is involved in antioxidant-mediated reactions in the apoplast, resulting in overcoming a possible redox imbalance.
\end{abstract}

(C) 2012 Elsevier GmbH. All rights reserved.

\section{Introduction}

All terrestrial organisms are exposed to the earth's electric and magnetic fields (EFs and MFs, respectively), which are natural components of their environment. However, interest in studying the effects of these natural phenomena on plants is strengthened by the increasing human activities that generate EF and MF. An EF is a field of force surrounding a charged particle, while a MF is a field of force surrounding a moving charged particle. A charged particle always has both a MF and an EF, and that is why EF and MF are associated with each other (Griffiths, 1999). They are two different fields with similar physical characteristics, and their effects on biological organisms show difference (McCann et al., 1993; Moon and Chung, 2000). Today, different intensities of MF and EF are used in

Abbreviations: MF, magnetic field; EF, electric field; CAT, catalase; GPOD, unspecific peroxidase; APX, ascorbate peroxidase; SOD, superoxide dismutase; GR, glutathione reductase; Asc, ascorbate; Glu, glutathione; G6PDH, glucose-6phosphate dehydrogenase; MDA, malonyldialdehyde.

* Corresponding author. Present address: Department of Molecular Biology and Genetics, Faculty of Science, Istanbul Medeniyet University, 34730, Istanbul, Turkey. Tel.: +90216 60228 04; fax: +90216602 2805 .

E-mail address: turgaycakmak@hotmail.com (T. Cakmak). a wide range of areas including electronic appliances, food sterilization, medical diagnostics, medical therapeutics, and levitation. A large volume of literature is available on the effects of MF and EF on biological organisms. High intensity MF and EF have been utilized for direct biological applications due to their destructive effects on biological samples (McCann et al., 1993). On the other hand, weak MF and EF have been reported to have beneficial effects on living organisms (Nechitailo and Gordeev, 2001; Phirke et al., 1996). Knowledge of the mechanisms of the action of MF and EF on various biological systems may be effectively used as a means of regulating the biological activity of these systems. Stimulatory effects of weak intensity EF have been reported on early growth (Costanzo, 2008) and flowering (Nechitailo and Gordeev, 2001), even if small decreases in the germination ratio and slight disruption of meristem architecture with distracted cell division ratio were reported (Wawrecki and Zagorska-Marek, 2007). Positive effects of weak intensity MF on plant characteristics, such as seed germination and early growth (Cakmak et al., 2010a; Vashisth and Nagarajan, 2010), shoot development and flowering (Aladjadjiyan, 2002) were reported. Moreover, effects of weak MF application on protein biosynthesis, cell division, nucleic acid content, and membrane ion movement were studied (Phirke et al., 1996; Stange et al., 2002). However, the underlying mechanism of these phenomena is 
still poorly understood because of the complexity of the biological responses.

Plants are fixed organisms exposed to environmental stresses. Efficient adaptive cellular mechanisms allow resistance to such stresses. When plants are exposed to different stress factors, a variety of free radicals and reactive oxygen species (ROS) are overproduced. Overproduction of ROS causes oxidative damage to DNA, lipids, and proteins, often leading to the cessation of the cell cycle, and apoptotic or necrotic cell death (Ahmad et al., 2008). On the other hand, at low levels, ROS are important signaling molecules and are effectively managed by several antioxidant molecules. To keep ROS levels in a balance, plants have evolved antioxidant defense mechanisms. These include enzymatic components such as superoxide dismutase (SOD, EC 1.15.1.1), ascorbate peroxidase (APX, EC 1.11.1.11), catalase (CAT, EC 1.11.1.6), peroxidase (POD, EC 1.11.1.7), and glutathione reductase (GR, EC 1.6.4.2), as well as non-enzymatic components, such as ascorbate (ASC) and glutathione (GSH) pool (Mittler, 2002). Enzymatic reaction of SOD with superoxide radicals results in the formation of $\mathrm{H}_{2} \mathrm{O}_{2}$. Produced $\mathrm{H}_{2} \mathrm{O}_{2}$ is then scavenged by CAT, nonspecific PODs and the ascorbate-glutathione cycle, where APX reduces it to $\mathrm{H}_{2} \mathrm{O}$ (Mittler, 2002). GR also plays a key role in antioxidant defense processes by reducing oxidized glutathione to GSH. Past research has focused mainly on the potential importance of symplastic antioxidant systems in the detoxification of the ROS. By contrast, relatively little attention has been paid to the potential for the detoxification of ROS in the apoplast. However, many well documented antioxidants such as APX, POD, SOD, and CAT are also located in the leaf apoplast (Cakmak and Atici, 2009; Polle et al., 1994). Therefore, adverse environmental factors are also capable of inducing the synthesis of ROS in apoplastic space as in the intracellular area. Thus, antioxidants located in the aqueous matrix of leaf cell walls constitute an important first line of defense against the environmental stress (Atici and Nalbantoglu, 2003).

Although some reports have investigated MF- or EF-induced oxidative stress and antioxidant response (Hajnorouzi et al., 2011; Sahebjamei et al., 2007; Wang et al., 2009), to our knowledge, there is no information available about MF- and EF-induced apoplastic antioxidant response, although initial events most likely occur in the apoplastic area of plant cells subjected to biotic and abiotic environmental factors. The objective of the present study was to assess the possible effects of weak static MF and EF on the antioxidant status of shallot leaves and to evaluate whether shifts in antioxidant status between apoplastic and symplastic area help plants adapt to a new environment. Shallot plants were chosen for effective evaluation of apoplastic and symplastic antioxidant status in response to weak MF and EF applications because the apoplastic space between cells in an onion leaf is larger than most other plant leaves, and more uniform exposure to leaf cells can be achieved because of the channeled cone-shaped structure of the leaves.

\section{Materials and methods}

\section{Plant growth and sampling}

Fresh shallot (Allium ascalonicum L.) bulbs were obtained from Fidanistanbul Inc. (Istanbul, Turkey). Six healthy bulbs for each group (control, MF applied, EF applied) were placed root down to the top of $50 \mathrm{ml}$ flasks filled with nutrient solution after slightly cleaning and rinsing the root region. The nutrient medium was as previously described (Somerville and Ogren, 1982), but at half strength [2.5 $\mathrm{mM} \mathrm{KNO}_{3}, 1,25 \mathrm{mM} \mathrm{KH}_{2} \mathrm{PO}_{4}$ (pH 5.6), $1 \mathrm{mM} \mathrm{MgSO}_{4}$, $1 \mathrm{mM} \mathrm{Ca}\left(\mathrm{NO}_{3}\right)_{2}, 25 \mu \mathrm{M}$ Fe-EDTA], supplemented with the reported micronutrient mix at $1 \times$ concentration. Flasks were placed in coils and between plates where MF and EF were generated, respectively.
Control groups were placed in coils where no MF was generated. Shallots were sprouted under weak static MF and EF with the magnitudes $7 \mathrm{mT} \mathrm{MF}$ and $20 \mathrm{kV} / \mathrm{m}$ EF for 17 days. The nutrient solution in flasks was renewed every $48 \mathrm{~h}$ to avoid soluble oxygen deficiency or possible infection. Sampling was performed on the 8 th, 12 th and 17 th days of growth in order to analyze possible weak MF- and EF-induced changes in the apoplastic and symplastic antioxidant systems in relation to the early leaf age. Control and application groups were kept at least $1 \mathrm{~m}$ away from each other to avoid any potential external influence. All samples were kept in well-controlled laboratory conditions of temperature $\left(22 \pm 2{ }^{\circ} \mathrm{C}\right)$ and illumination (16 h:8 h light/dark circle).

At harvest, roots and leaves of shallots were separated; the length of each part was measured with a $0.1 \mathrm{~cm}$ precision and weighed with $10^{-4} \mathrm{~g}$ accuracy. Shoots and roots were dried at $80^{\circ} \mathrm{C}$ for $48 \mathrm{~h}$ to determine dry biomass. Extraction of apoplastic and symplastic proteins was performed immediately at each time point. Samples required for ascorbate, glutathione, $\mathrm{H}_{2} \mathrm{O}_{2}$ and malonyldialdehyde (MDA) determinations were weighed, frozen in liquid nitrogen and stored at $-80^{\circ} \mathrm{C}$ for further use.

\section{Magnetic and electric field exposure}

The body material of coils used for magnetic treatment was made of several layers of wood laminated and glued to each other. The coil dimension was $30 \mathrm{~cm}$ long with an inner radius of $17 \mathrm{~cm}$; the outer radius of each was $28 \mathrm{~cm}$ and $24 \mathrm{~cm}$, respectively. Each of the coils was located in a vertical position. The MF application was carried out in the coil at a vertical position of $6-26 \mathrm{~cm}$ above the coil bottom, where a uniform MF was obtained. The exposure magnitude of the MF did not at any point deviate more than $6 \%$ from the center value. A ventilation system around the coils was employed to avoid an overheating effect from the current in the coils. The temperature deviation inside the coils was negligible $\left(23 \pm 2^{\circ} \mathrm{C}\right)$. The required current $(0.426 \mathrm{~A})$ and voltage $(36 \mathrm{~V})$ to generate $\mathrm{MF}$ was provided by power supplies (Global dual power supply Model no: 3521 , Wilmington, USA). The number of turns of wire was 17,000 and the wire diameter was $1 \mathrm{~mm}$. Static continuous MF in the axial center of the coils was measured as $7 \mathrm{mT}$ with a gauss meter (F.W. Bell Gauss meter Model no: 5080, Delaware, USA).

The EF intensity was determined as the ratio of electric voltage charged on plates to the distance between them. The electric field was created between two parallel aluminum plates, whose diameters were $50 \mathrm{~cm}$ and distance between two plates was $75 \mathrm{~cm}$. A $50 \mathrm{~Hz}, 15 \mathrm{kV}$ DC voltage was applied to obtain EF intensity of $20 \mathrm{kV} / \mathrm{m}$. A diagram of the experiment is shown in Fig. 1.

\section{Enzyme extraction}

Apoplastic proteins from leaves were extracted as described previously (Vanacker et al., 1998) with some modifications. Harvested fresh leaves $(6 \mathrm{~g})$ were carefully cut with a sharp bistoury into $1 \mathrm{~cm}$ lengths and rinsed in 6 changes of distilled water to remove cellular proteins and epicuticular waxes from the cut ends. The leaves were then vacuum-infiltrated for $15 \mathrm{~min}$ in $20 \mathrm{mM}$ ascorbic acid and $20 \mathrm{mM} \mathrm{CaCl}_{2}$ solution. The leaves were blotted dry and placed vertically in a $20 \mathrm{ml}$ syringe. The syringes were placed in centrifuge tubes. The apoplastic extract was collected from the bottom of the tubes after the leaves were centrifuged at $1500 \times \mathrm{g}$ for $20 \mathrm{~min}$ at $4{ }^{\circ} \mathrm{C}$. Then apoplastic extract fluid was centrifuged twice at $1500 \times g$ for $5 \mathrm{~min}$ at $4{ }^{\circ} \mathrm{C}$ to remove epicuticular waxes. After centrifugation, the supernatant was taken and proteins were precipitated from apoplastic supernatant by adding 1.5 times $(\mathrm{v} / \mathrm{v}) \mathrm{MeOH}$ containing $1 \%$ acetic acid and incubated the samples overnight at $-20^{\circ} \mathrm{C}$. Then supernatant samples were centrifuged at $3500 \times g$ for $20 \mathrm{~min}$, protein pellets were washed with 


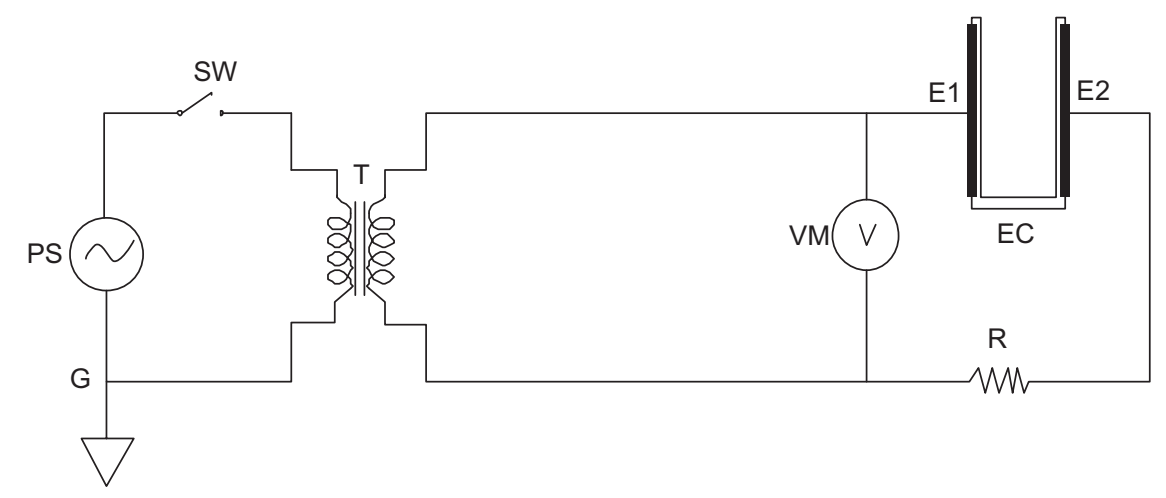

$\begin{array}{llll}\text { SW } & \text { : Switch } & \text { EC } & \text { : Electric field cell } \\ \text { T } & : \text { HV transformer } & \text { R } & : \text { Resistor } \\ \text { VM } & \text { : Voltmeter } & \text { PS } & : \text { AC 220 V, } 50 \mathrm{~Hz} \\ \text { E1, E2 } & \text { : Aluminum electrodes } & \text { G } & : \text { Ground }\end{array}$

Fig. 1. Set up for electric field treatment.

$100 \%$ ice-cold EtOH and $70 \%$ ice-cold EtOH, and stored at $-80^{\circ} \mathrm{C}$ for further use of apoplastic enzyme activity determinations (Tasgin et al., 2006). Protein content of the apoplastic supernatant after protein precipitation was never detected over more than $7 \%$ of the precipitated proteins.

Following collection of apoplastic proteins, the residual leaf material was pulverized in liquid nitrogen by means of a mortar and a pestle. For enzyme extracts, $1 \mathrm{~g}$ leaf was homogenized in $10 \mathrm{ml}$ of extraction buffer $\left(50 \mathrm{mM} \mathrm{KH}_{2} \mathrm{PO}_{4}, \mathrm{pH} 7.8\right.$ containing $2 \%$ soluble polyvinylpyrrolidone, $0.5 \mathrm{mM}$ ascorbate and $1 \mathrm{mM}$ EDTA). Homogenate was centrifuged at $13,000 \times g$ for $40 \mathrm{~min}$ at $4{ }^{\circ} \mathrm{C}$ and supernatant was centrifuged twice at $1500 \times \mathrm{g}$ for $5 \mathrm{~min}$ at $4{ }^{\circ} \mathrm{C}$ to remove epicuticular waxes. Then supernatant was frozen in liquid nitrogen and stored at $-80^{\circ} \mathrm{C}$ for further use as enzyme extract.

\section{Determination of enzyme activities}

The dried apoplastic protein pellets obtained from the leaves were dissolved in $0.2 \mathrm{M}$ phosphate buffer ( $\mathrm{pH}$ 6.5). Symplastic enzyme extract was thawed and used for protein level and enzyme activity determinations. Protein estimation of apoplastic and symplastic fluids was carried out using the method of Bradford (Bradford, 1976) using bovine serum albumin as standard.

Glucose-6-phosphate dehydrogenase (G6PDH, EC 1.1.1.49) activity was used to assess the contamination degree of apoplastic extract by cytoplasmic constituents. Activity was measured according to the protocol as described before (Kornberg and Horecker, 1955). The reduction of NADP at $340 \mathrm{~nm}$ was followed using an assay containing $66 \mathrm{mM}$ potassium phosphate buffer ( $\mathrm{pH} 7.6$ ), $10 \mathrm{mM} \mathrm{MgCl}_{2}$, $300 \mu \mathrm{M}$ NADP, 2 mM glucose-6-phosphate and $50 \mu \mathrm{l}$ extract. The activity of G6PDH was calculated using an extinction coefficient of $6.22 \mathrm{mM}^{-1} \mathrm{~cm}^{-1}$ for NADPH at $340 \mathrm{~nm}$.

Catalase (CAT, EC 1.11.1.6) activity was measured by monitoring the decrease in absorbance at $240 \mathrm{~nm}$ in $50 \mathrm{mM}$ phosphate buffer ( $\mathrm{pH} 7.5$ ) containing $20 \mathrm{mM} \mathrm{H}_{2} \mathrm{O}_{2}$. The activity of CAT was calculated using an extinction coefficient of $43.6 \mathrm{mM}^{-1} \mathrm{~cm}^{-1}$ for $\mathrm{H}_{2} \mathrm{O}_{2}$ at $240 \mathrm{~nm}$ (Beers and Sizer, 1952).

Unspecific peroxidase (GPOD, EC 1.11.1.7) activity was measured by monitoring the increase in absorbance at $470 \mathrm{~nm}$ in $50 \mathrm{mM}$ phosphate buffer ( $\mathrm{pH} 5.5$ ) containing $1 \mathrm{mM}$ guaiacol and $0.5 \mathrm{mM}$ $\mathrm{H}_{2} \mathrm{O}_{2}$. The activity of GPOD was calculated using an extinction coefficient of $26.6 \mathrm{mM}^{-1} \mathrm{~cm}^{-1}$ for guaiacol at $470 \mathrm{~nm}$ (Upadhyaya et al., 1985).
Superoxide dismutase (SOD, EC 1.15.1.1) activity was estimated by recording the decrease in optical density of nitro-blue tetrazolium dye by the enzyme (Dhindsa et al., 1981). Three milliliters of the reaction mixture contained, $2 \mu \mathrm{M}$ riboflavine, $13 \mathrm{mM}$ methionine, $75 \mu \mathrm{M}$ nitroblue tetrazolium chloride (NBT), $0.1 \mathrm{mM}$ EDTA, $50 \mathrm{mM}$ phosphate buffer ( $\mathrm{pH} 7.8$ ), $50 \mathrm{mM}$ sodium carbonate and $0.1 \mathrm{ml}$ from the apoplastic fraction. Reaction was started by adding $60 \mu \mathrm{L}$ from $100 \mu \mathrm{M}$ riboflavin solution and placing the tubes under two $30 \mathrm{~W}$ fluorescent lamps for $15 \mathrm{~min}$. A complete reaction mixture without enzyme, which yielded the maximal color, served as control. Reaction was stopped by switching off the light. A non-irradiated complete reaction mixture served as a blank. The absorbance was recorded at $560 \mathrm{~nm}$, and one unit of enzyme activity was that amount of enzyme which reduced the absorbance reading to $50 \%$ in comparison with tubes lacking enzyme.

Glutathione reductase (GR, EC 1.6.4.2) activity was determined following the oxidation of NADPH at $340 \mathrm{~nm}$ (Foyer and Halliwell, 1976). The assay mixture contained $25 \mathrm{mM}$ sodium phosphate buffer ( $\mathrm{pH} 7.8$ ), $0.12 \mathrm{mM} \mathrm{NADPH}, 0.5 \mathrm{mM}$ oxidized glutathione (GSSG) and $0.1 \mathrm{ml}$ enzyme extract in a final assay volume of $1 \mathrm{ml}$. Corrections were made for any NADPH oxidation in the absence of GSSG. The activity of GR was calculated using a molar extinction coefficient of $6.22 \mathrm{mM}^{-1} \mathrm{~cm}^{-1}$ for NADPH at $340 \mathrm{~nm}$.

Ascorbate peroxidase (APX, EC 1.11.1.11) activity was determined as detailed in Nakano and Asada (1981). The assay mixture contained $50 \mathrm{mM}$ potassium phosphate buffer ( $\mathrm{pH} 7.0), 0.5 \mathrm{mM}$ ascorbic acid, $1.2 \mathrm{mM} \mathrm{H} \mathrm{H}_{2}, 0.1 \mathrm{mM}$ EDTA and $0.1 \mathrm{ml}$ enzyme extract in a final assay volume of $1 \mathrm{ml}$. Enzyme activity was calculated using a molar extinction coefficient of $2.8 \mathrm{mM}^{-1} \mathrm{~cm}^{-1}$ for ascorbate at $290 \mathrm{~nm}$.

\section{Quantitation of ascorbate and glutathione}

Extraction of ascorbate and glutathione was accomplished as described previously (Noctor and Foyer, 1998). Fresh leaf material $(0.5 \mathrm{~g})$ was ground in liquid nitrogen and then extracted into $2 \mathrm{ml} 0.2 \mathrm{~N} \mathrm{HCl}$. The homogenate was transferred into Eppendorf tubes and centrifuged at $16,000 \times \mathrm{g}$ for $10 \mathrm{~min}$ at $4{ }^{\circ} \mathrm{C}$. A $0.5 \mathrm{ml}$ supernatant was neutralized with $50 \mu \mathrm{NaH}_{2} \mathrm{PO}_{4}(0.2 \mathrm{M}$, pH 5.6) and $0.4 \mathrm{ml} \mathrm{NaOH}(0.2 \mathrm{M})$. The final $\mathrm{pH}$ was between 5 and 6 . The levels of ascorbate and glutathione were measured using previously described enzyme-linked spectrophotometric methods (Queval and Noctor, 2007). The total ascorbate level was quantified 
after conversion of dehydroascorbate to ascorbate by incubation of the neutralized supernatant with $1 \mathrm{mM}$ dithiothreitol (DTT) in $\mathrm{NaH}_{2} \mathrm{PO}_{4}$ buffer $(0.1 \mathrm{M}, \mathrm{pH} 7.5)$ for $30 \mathrm{~min}$. For ascorbate measurement, the initial absorbance of a $30 \mu \mathrm{l}$ of supernatant (incubated with $1 \mathrm{mM}$ DTT) was measured at $265 \mathrm{~nm}$ in $\mathrm{NaH}_{2} \mathrm{PO}_{4}(0.1 \mathrm{M}, \mathrm{pH}$ 5.6), then re-measured over 3 min following the addition of Ascorbate Oxidase $(0.5 \mathrm{U})$. An extinction coefficient of $12.6 \mathrm{mM}^{-1} \mathrm{~cm}^{-1}$ for ascorbate at $265 \mathrm{~nm}$ was used for calculation. The method followed for glutathione measurement relies on the GR-dependent reduction of 5,5'-dithiobis(2-nitrobenzoic acid) (DTNB) monitored at $412 \mathrm{~nm}$. The assay mixture used for glutathione measurement contains $100 \mathrm{mM} \mathrm{NaH}_{2} \mathrm{PO}_{4}(\mathrm{pH} 7.8), 0.6 \mathrm{mM}$ DTNB, $6 \mathrm{mM}$ EDTA, $0.1 \mathrm{mM}$ NADPH, $25 \mu \mathrm{l}$ extract and 0.6U GR. The change in absorbance at $412 \mathrm{~nm}$ was recorded for $5 \mathrm{~min}$. Glutathione concentrations were calculated from a standard curve constructed using GSH over the range of $0-1 \mathrm{nmol}\left(y=1.143 x-0.0453, R^{2}=0.993\right)$.

\section{Determination of the malonyldialdehyde and hydrogen peroxide} levels

The thiobarbituric acid (TBA) test, which determines malonyldialdehyde (MDA) as an end product of lipid peroxidation, was employed to measure lipid peroxidation in the leaves of shallots. Briefly, $1 \mathrm{~g}$ of leaf sample was homogenized in $5 \mathrm{ml} 80 \%$ ethanol solution with a mortar and pestle. The homogenate was centrifuged at $3000 \times g$ for $20 \mathrm{~min}$ and $2 \mathrm{ml}$ of supernatant was aliquoted into two Eppendorf tubes as $1 \mathrm{ml}$ per tube. Then; 20\% trichloroacetic acid (TCA) $(\mathrm{w} / \mathrm{v})$ solution including $0.01 \%(\mathrm{w} / \mathrm{v})$ butylated hydroxytoluene and $0.65 \%$ TBA $(\mathrm{w} / \mathrm{v})$, or $1 \mathrm{ml} 20 \%$ TCA solution including $0.01 \%(\mathrm{w} / \mathrm{v})$ butylated hydroxytoluene was added into these aliquots and they were incubated at $95^{\circ} \mathrm{C}$ for $20 \mathrm{~min}$. The reaction was stopped by placing the reaction tubes in an ice bath for $5 \mathrm{~min}$ and then the samples were centrifuged at $3000 \times g$ for $10 \mathrm{~min}$. The absorbance of the supernatants was monitored at $532 \mathrm{~nm}$ for MDA compounds, $440 \mathrm{~nm}$ and $600 \mathrm{~nm}$ for correction of anthocyanin and sugar absorbance. The MDA equivalents were calculated using an extinction coefficient of $157 \mathrm{mM}^{-1} \mathrm{~cm}^{-1}$ as described previously (Hodges et al., 1999).

For $\mathrm{H}_{2} \mathrm{O}_{2}$ determination, $1 \mathrm{~g}$ of leaf sample was ground in liquid nitrogen and homogenized in $5 \mathrm{ml}$ of $0.1 \%(\mathrm{w} / \mathrm{v})$ TCA. The homogenate was centrifuged at $12,000 \times g$ for $15 \mathrm{~min}$. An aliquot $(1 \mathrm{ml})$ of the supernatant was mixed with an equal volume of $10 \mathrm{mM}$ potassium phosphate buffer $(\mathrm{pH} 7.0)\left(\mathrm{KH}_{2} \mathrm{PO}_{4}\right)$ and $1 \mathrm{ml}$ of $1 \mathrm{M} \mathrm{KI}$. The absorbance of the mixture was monitored at $390 \mathrm{~nm}$. The content of $\mathrm{H}_{2} \mathrm{O}_{2}$ was calculated by using a standard curve (Velikova et al., 2000).

Two independent experiments, with three replicates for each measurement, were performed. All data were expressed as the mean values \pm standard deviation (SD). Statistical analysis was carried out from row data using two tailed probability values of the student's $t$-test and the differences between treatments were expressed as significant at a level of $P<0.05,0.01$, or 0.001 significance criterion.

\section{Results and discussion}

The world's natural MF has been reported as 25-65 $\mu \mathrm{T}$ and EF has been calculated as $100-140 \mathrm{~V} / \mathrm{m}$ in rural areas (Belyavskaya, 2004; Neamtu and Morariu, 2005). However, they can show dramatic increases in industrialized regions (Isobe et al., 1999). According to the report released in 2001 by the American Conference of Governmental Industrial Hygenists Organization, occupational threshold limit values for workers were defined as $25 \mathrm{kV} / \mathrm{m}$ EF and $10 \mathrm{mT}$ MF (Belyavskaya, 2004). In this study, we wanted to assess the possible effects of weak static MF ( $7 \mathrm{mT})$ and
$\mathrm{EF}(20 \mathrm{kV} / \mathrm{m})$ on the antioxidant status of plant leaves. The shallot plant was chosen due to the feasibility to extract apoplastic fluids for effective evaluation of apoplastic and symplastic antioxidant status in leaves in response to weak MF and EF applications.

Plants have the ability to adjust their metabolism according to changing environmental conditions. They accelerate their metabolism and grow faster when optimal conditions develop. However, when a stress condition arises, plants generally decelerate their metabolism and limit their growth (Atici and Nalbantoglu, 2003). In this study, root and leaf length increased in response to MF but these effects were not observed in response to EF application (Table 1). Moreover, weak MF induced sprouting approximately one day earlier than other groups. Emergence of the first leaf was observed on 6th day of the incubation. Root and leaf dry biomass increased in response to EF and MF applications. Increases were found to be relatively higher under EF application (Table 1). In plants, the reactive oxygen species (ROS) production level increases under stress conditions or at some growth stages (e.g., germination, early growth, senescence). At certain levels, increases in ROS production imply either increased metabolic activity or possible redox imbalance depending on changes in the levels of oxidative stress markers such as lipid peroxidation and protein carbonylation (Mittler, 2002). Our results showed that $\mathrm{H}_{2} \mathrm{O}_{2}$ levels decreased, but the level of MDA compounds, which are end products of lipid peroxidation, remained unchanged depending on leaf age (Fig. $2 \mathrm{a}$ and $b$ ). Younger leaves had a higher $\mathrm{H}_{2} \mathrm{O}_{2}$ but approximately the same MDA compound levels, which reflects the fact that they have a higher metabolic activity than older ones. An increase in ROS levels, to some extent, was reported as an indicator of metabolic activity in plants (Mittler, 2002). Moreover, $\mathrm{H}_{2} \mathrm{O}_{2}$ and MDA levels did not show a considerable change in MF applied leaves, but both increased significantly in EF applied leaves when compared to their respective controls (Fig. $2 \mathrm{a}$ and b). These results show that $7 \mathrm{mT}$ MF application does not, but $20 \mathrm{kV} / \mathrm{m} \mathrm{EF}$ application may, form a stress factor on shallot growth.

Under stress conditions or increased metabolic activities at some growth stages, plants generally increase the activity of one or more antioxidant molecules, and the elevated activity levels usually correlate with increased stress tolerance (Mittler, 2002). Therefore, resistance to stress or the holding maximum growth rate under prevailing environmental conditions is related to a plant's antioxidant capacity, which counteracts redox imbalance by scavenging overproduced ROS. In addition, many studies have suggested that enzyme systems localized at the cell surface or apoplast are important sources of superoxide $\left(\mathrm{O}_{2}{ }^{-}\right)$and $\mathrm{H}_{2} \mathrm{O}_{2}$ production (Tasgin et al., 2006). The antioxidant enzymes in apoplast spaces of plants have important roles in the removal of ROS under both normal and stress conditions (Cakmak and Atici, 2009; Patykowski and Urbanek, 2003). However, a possible correlation between apoplastic and symplastic antioxidant pool is not well documented, and to our knowledge, there is no study reported thus far on the evaluation of EF or MF effects on apoplastic and symplastic antioxidant systems in plants. Our results showed that the soluble protein level in symplastic areas slightly increased in response to MF (Fig. 3a). On the other hand, 12 days of MF application caused more than a two-fold increase in protein levels and a statistically important decrease in protein level was observed in apoplastic washing fluid at the end of 17 days of EF application (Fig. 3b). These results show that different enzymatic regulation patterns may exist in apoplastic and symplastic areas of shallot leaves in response to MF and EF applications.

Before starting enzymatic activity determinations, we measured G6PDH activity to examine whether there was contamination of symplastic fluid into apoplastic areas. Activity of G6PDH in apoplastic washing fluid of all leaf samples was below the detection limits while symplastic G6PDH activity increased on 12 th and 17 th days of 
Table 1

Changes in the length and dry biomass of shallot root and leaves under EF and MF conditions.

\begin{tabular}{|c|c|c|c|c|c|c|c|c|c|}
\hline \multirow[t]{2}{*}{ Parameters } & \multicolumn{3}{|l|}{ Control } & \multicolumn{3}{|l|}{$7 \mathrm{mT} \mathrm{MF}$} & \multicolumn{3}{|l|}{$20 \mathrm{kV} / \mathrm{m} \mathrm{EF}$} \\
\hline & Day 8 & Day 12 & Day 17 & Day 8 & Day 12 & Day 17 & Day 8 & Day 12 & Day 17 \\
\hline Leaf length (cm) & $4.63 \pm 0.21$ & $9.28 \pm 0.71$ & $14.11 \pm 1.27$ & $6.12 \pm 0.81^{*}$ & $12.4 \pm 1.15^{*}$ & $17.8 \pm 2.1^{*}$ & $4.1 \pm 0.67$ & $10.6 \pm 0.22$ & $14.26 \pm 2.25$ \\
\hline Root length $(\mathrm{cm})$ & $3.52 \pm 0.68$ & $3.91 \pm 0.22$ & $4.42 \pm 0.34$ & $4.12 \pm 0.68$ & $4.7 \pm 0.43^{*}$ & $5.58 \pm 0.41^{*}$ & $3.65 \pm 0.21$ & $3.36 \pm 0.85$ & $4.71 \pm 0.44$ \\
\hline Leaf dry biomass (\%) & $5.71 \pm 0.44$ & $5.87 \pm 0.55$ & $6.37 \pm 0.21$ & $6.15 \pm 0.22$ & $5.81 \pm 0.62$ & $7.38 \pm 0.38^{*}$ & $6.72 \pm 0.48^{*}$ & $6.95 \pm 0.29^{*}$ & $7.65 \pm 0.36^{*}$ \\
\hline Root dry biomass (\%) & $6.24 \pm 0.36$ & $6.46 \pm 0.25$ & $6.85 \pm 0.62$ & $6.62 \pm 0.51$ & $7.2 \pm 0.47$ & $6.87 \pm 1.07$ & $7.18 \pm 0.27^{*}$ & $7.64 \pm 0.51^{*}$ & $8.42 \pm 0.46^{*}$ \\
\hline
\end{tabular}

Data are means $\pm S E$ of at least six separate measurements.

A significant difference from the control in $t$-test at $P<0.05$ in the same day.
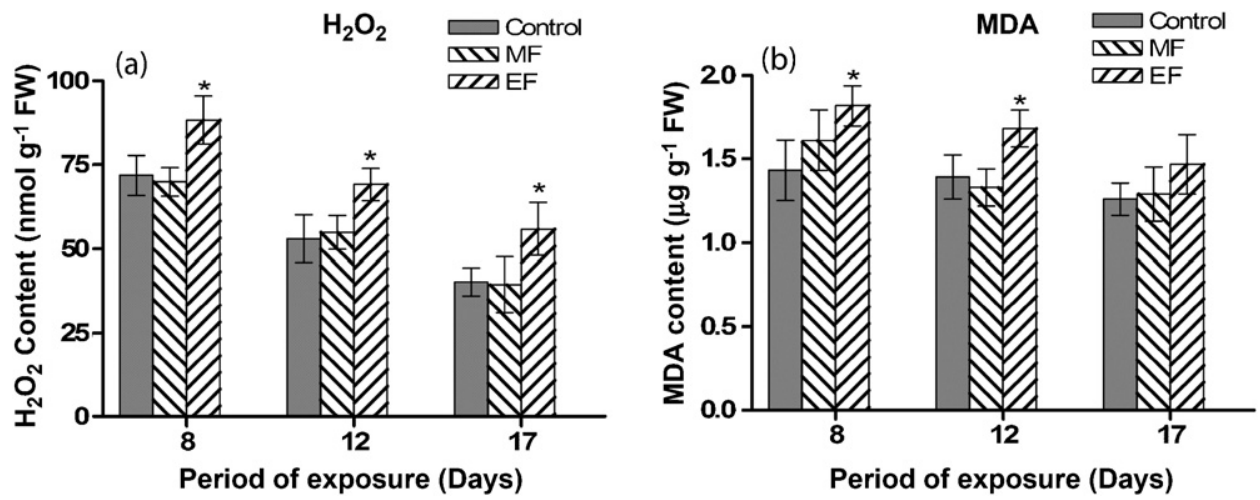

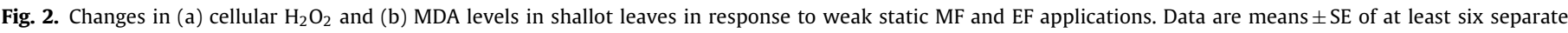
measurements. Asterisk in the same column denote a significant difference from the control in $t$-test at $P<0.05$.

MF and EF applications (Fig. 5a). Apoplastic washing fluid isolated from shallot leaves was found to contain CAT, GPOD, APX, and SOD, but not GR. This is consistent with previous reports (Patykowski and Urbanek, 2003).

In this study, symplastic GPOD activity increased while no significant change was observed in apoplastic areas in response to MF during all days studied (Fig. 4a and b). On the other hand, symplastic GPOD activity did not change, but apoplastic GPOD activity decreased in response to EF application (Fig. 4a and b). Unspecific PODs protect cells against damaging effects of $\mathrm{H}_{2} \mathrm{O}_{2}$ during an oxidative-burst response which occurs as a result of cellular redox changes. Apoplastic PODs are bound to cell wall polymers by ionic or covalent bonds, and were reported to be easily released from the cell wall into the apoplast and play a critical role in regulating the wall stiffening process (De Pinto and De Gara, 2004), and many other functions related to their ROS scavenging activity (Xue et al., 2008) under normal and stress conditions. Our results show that EF application may impede cell wall lignification process by affecting chemical composition of apoplastic GPOD and some other related enzymes bound to cell wall polymers. Symplastic GPOD activity decreased, but apoplastic GPOD activity did not show a significant quantitative change depending on leaf age in any of the groups studied. The functional significance of such changes in cell wall properties under the influence of MF and EF are worthy of detailed investigation.

Remarkably, both CAT and SOD activities in apoplastic and symplastic areas increased in response to MF and $\mathrm{EF}$ applications (Fig. 4c-f). However, increases in enzyme activities were found to be higher in response to EF. Of the antioxidant enzymes, SOD catalyzes the conversion of two superoxide molecules to hydrogen peroxide and oxygen, and hydrogen peroxide is eliminated mainly by CAT. Increased CAT and SOD activities have been related to increased metabolic activity, cold tolerance (Cakmak and Atici, 2009; Clare et al., 1984), freezing tolerance (Cakmak et al., 2010b; McKersie et al., 1993), and salt stress tolerance (Yazici et al., 2007). In this study, apoplastic SOD activity did not change but symplastic
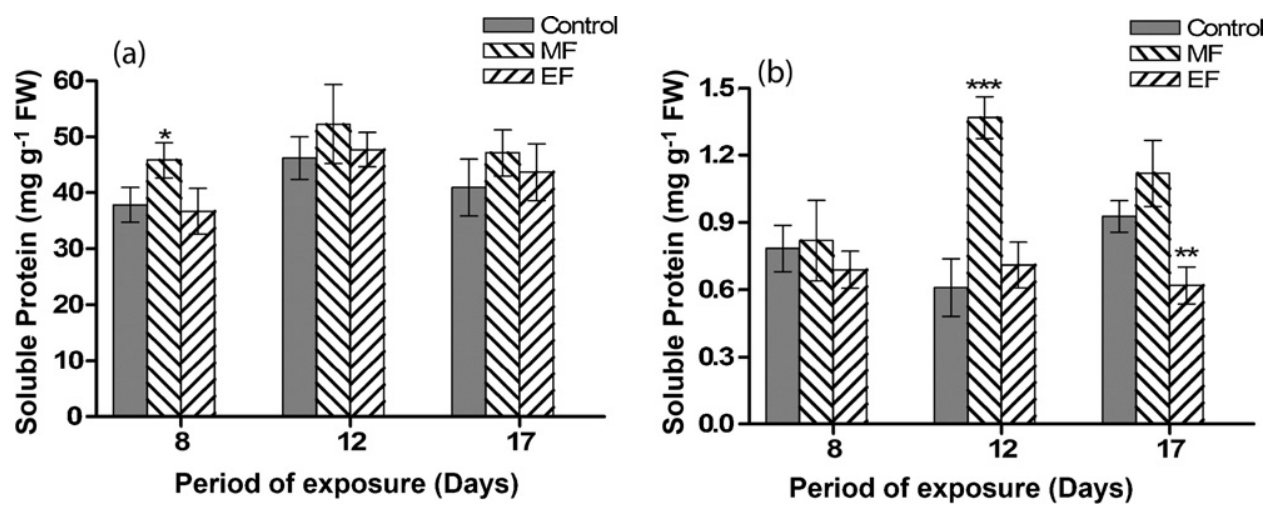

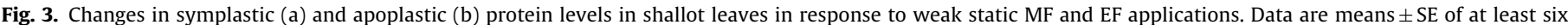

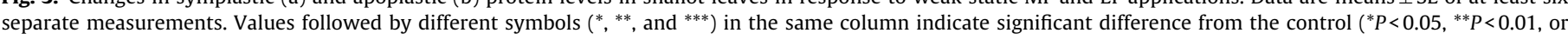
$\left.{ }^{* * *} P<0.001\right)$. 

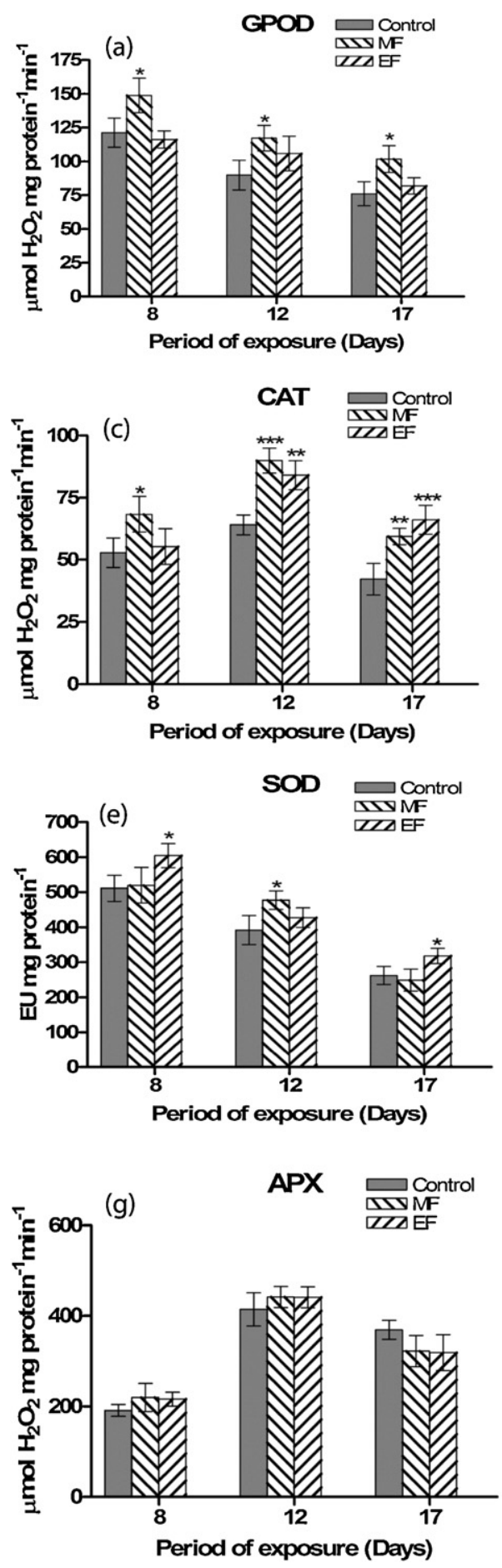
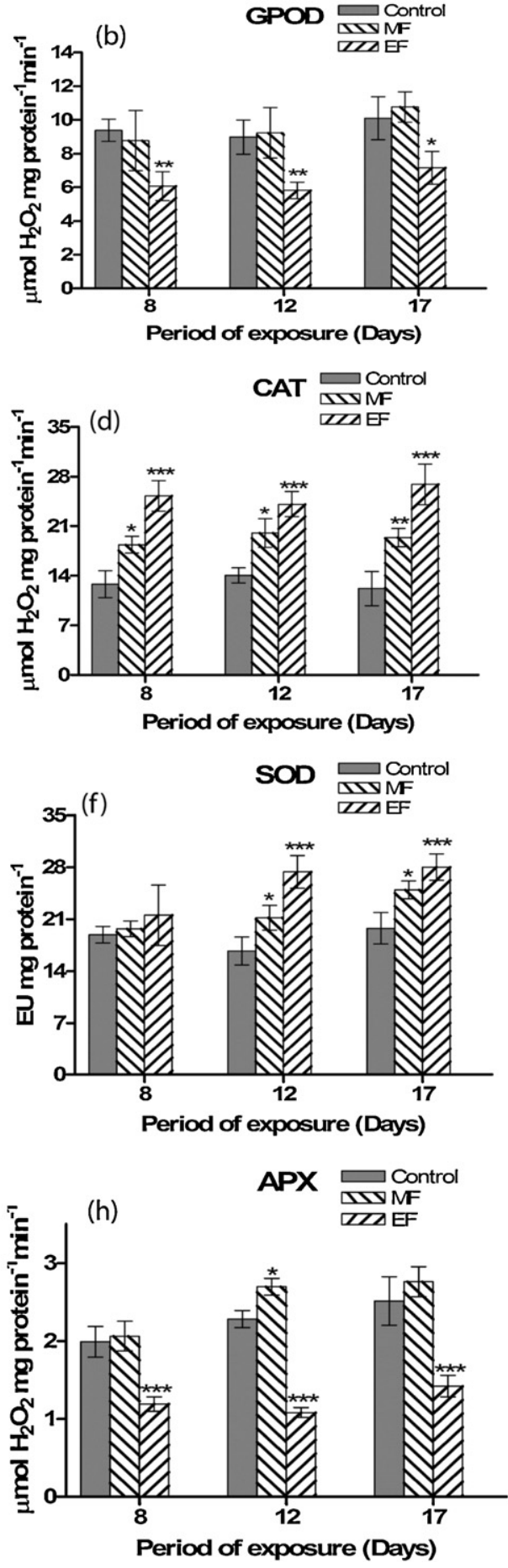

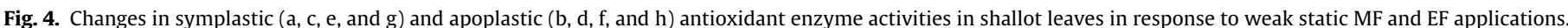

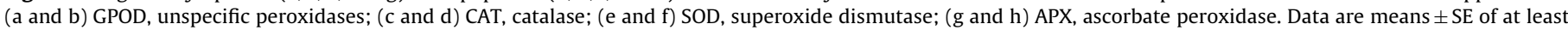

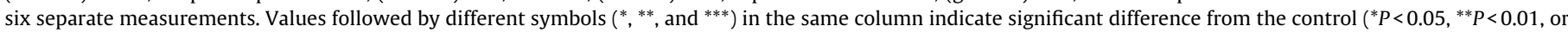
*** $P<0.001)$.

SOD activity decreased quantitatively depending on leaf age in all groups studied (Fig. 4e and f). Indeed, full function of this enzyme is not well documented. It is therefore difficult to assess the significance of the decrease in the activity of this enzyme in the symplast depending on the age of the leaf. Apoplastic SOD has been associated with cell wall lignification (Kukavica et al., 2009). Thus, a possible conclusion from our results might be that some of the symplastic SOD molecules might be transferred to the apoplastic area in order to help cell wall strengthening depending on leaf age.
Increased apoplastic SOD activity in response to EF application supports this hypothesis, as apoplastic SOD was also implicated in the perception and signaling of oxidative stress (Foyer et al., 1997).

Symplastic APX activity did not change in response to MF and EF applications (Fig. $4 \mathrm{~g}$ and $\mathrm{h}$ ), but symplastic GR activity increased during 12 days of EF application while there was no significant change in response to MF (Fig. 5b). On the other hand, apoplastic APX activity sharply decreased in EF applied leaves but it either increased or remained unaffected in MF applied leaves. To our 

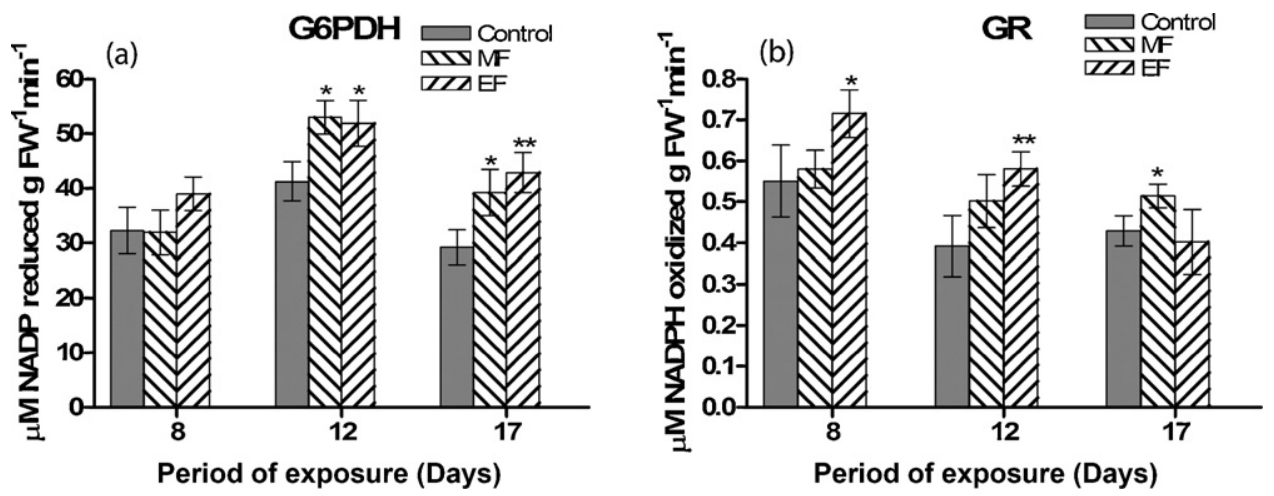

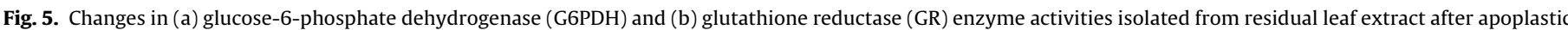

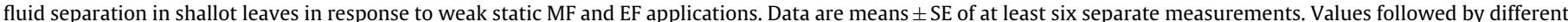
symbols $\left({ }^{*}\right.$ or $\left.{ }^{* *}\right)$ in the same column indicate significant difference from the control $\left({ }^{*} P<0.05\right.$ or $\left.{ }^{* *} P<0.01\right)$.

knowledge, there is no study thus far reported on effects of MF and EF on apoplastic antioxidant status, but researchers reported different results of MF and EF effects on cellular antioxidant enzyme activities in plants. It has been reported that weak static MFs ( 10 and $30 \mathrm{mT}$ for 5 days, 5 h each day) increased SOD but decreased CAT and APX enzyme activities in tobacco cell lines (Sahebjamei et al., 2007). Supported with increased level of lipid peroxidation, these authors concluded that weak MF could have deteriorative effect on antioxidant defense system of plant cells. On the other hand, magnetically $(180 \mathrm{mT})$ pretreated lentil seeds grew faster and appeared as more resistant to drought with the increased SOD and APX activities (Shabrangi and Majd, 2009). A comprehensive study was reported on the stimulation of germination and early growth of rice by using high-voltage EFs in the range of $250-450 \mathrm{kV} / \mathrm{m}$ (Wang et al., 2009). They observed induced activities of antioxidant enzymes (SOD, APX, and CAT), and lowered malonyldialdehyde content in response to a $300 \mathrm{kV} / \mathrm{m}$ EF for $30 \mathrm{~min}$ right before germination. They concluded that a high-voltage EF could elevate the aged rice seeds' vigor and improve the membrane system of aged rice seedlings. In addition, our previous investigation (Cakmak et al., 2010b) showed that short term (10 and $40 \mathrm{~min}$ ) EF application with a magnitude of $100 \mathrm{kV} / \mathrm{m}$ does not have a significant effect on antioxidant enzyme activities under normal growth conditions. However, $10 \mathrm{~min}$ EF right before cold application could augment chilling resistance of cold-sensitive bean species with increased CAT and SOD activities. In this study, we observed significant increases of oxidative stress markers $\left(\mathrm{H}_{2} \mathrm{O}_{2}\right.$ and lipid peroxidation levels) in response to EF application but not to MF (Fig. 2a and b). Moreover, increased CAT and SOD activities were followed by decreased APX activity in the apoplastic area of EF applied shallot leaves. However, apoplastic APX activity either increased or remained unaffected by MF (Fig. 4). Both CAT and APX are involved in scavenging $\mathrm{H}_{2} \mathrm{O}_{2}$ and they have distinct affinity levels for $\mathrm{H}_{2} \mathrm{O}_{2}$. Catalase has been reported as a primary enzyme that effectively eliminates the bulk of $\mathrm{H}_{2} \mathrm{O}_{2}$ while APX can scavenge low levels of $\mathrm{H}_{2} \mathrm{O}_{2}$ that is not removed by CAT as it has higher affinity for $\mathrm{H}_{2} \mathrm{O}_{2}$ compared to CAT (Dat et al., 2001; Ghanati et al., 2005). In addition, similar changes in apoplastic APX and POD activities (Fig. 4) in response to MF and EF show that peroxidases are important elements of the apoplast taking on the task of sensing and signaling environmental changes.

In this study, increases in GR and G6PDH activities were more pronounced in EF applied leaves than MF applied ones in general (Fig. 5a and b). Glucose-6-phosphate dehydrogenase is the first enzyme of the pentose phosphate pathway. Thus, an increase in this enzyme activity supported with increased GR activity may indicate that ascorbate-glutathione pathway works faster in EF applied leaves. In this case, EF applied leaves are expected to have higher levels of ascorbate and glutathione. However, increases in ascorbate and glutathione levels were more pronounced in MF applied leaves than EF applied ones (Fig. 6a and b). Such effects remain to be investigated in $A$. ascalonicum.

In conclusion, the data presented in this paper indicate that weak MF promote growth, possibly by increasing antioxidant system activity, but EF has some negative effects on shallot growth despite a lack of visible symptoms of injury. An increase in growth in response to MF, change in metabolic activity depending on leaf age, and slight oxidative stress caused by EF are directly related to collaboration between apoplastic and symplastic antioxidant
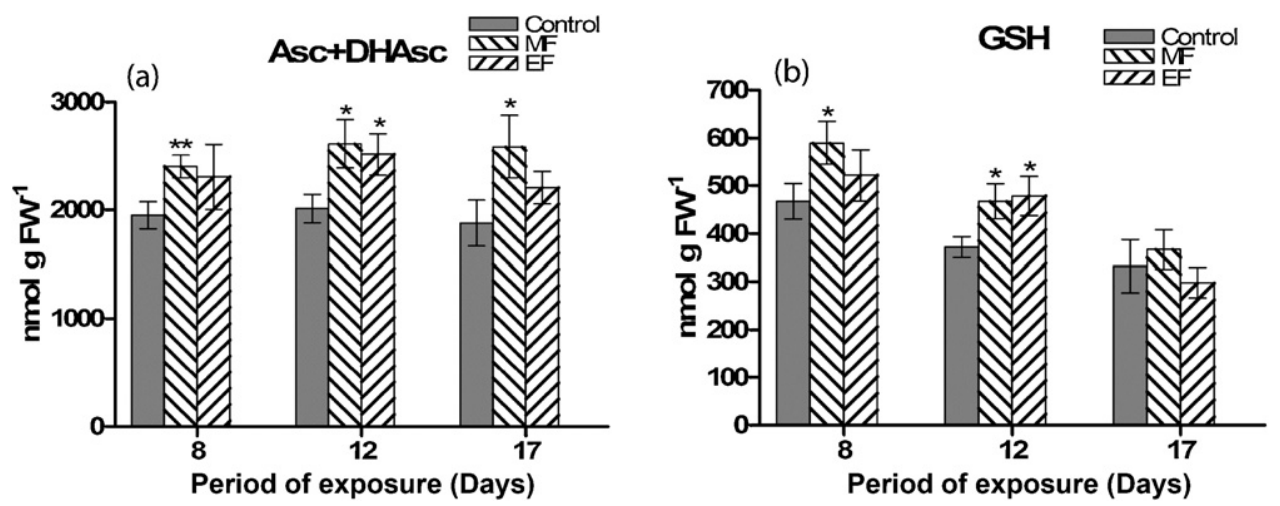

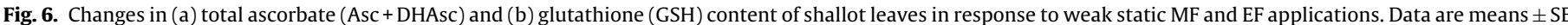

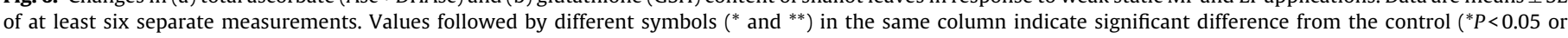
$\left.{ }^{* *} P<0.01\right)$. 
activity of leaf cells. Differential activity levels of apoplastic and symplastic ROS scavengers in response to MF and EF showed that the apoplastic area is as important as the symplastic area for sensing and overcoming a stress factor. Shifts in antioxidant status of the apoplast and symplast contribute to redox regulation and help plants adapt to a new environment. Lastly, weak MF applications may be involved in antioxidant-mediated reactions in apoplast resulting in overcoming of possible redox imbalance. Thus, weak MF can be used as an effective means for augmenting plant resistance to different stress factors. To uncover possible practical applications of weak EF and MF in agriculture, more research on the effects of weak MF and EF applications on growth and biochemical response in plants is necessary. Our ongoing studies are focused on the potential importance of apoplastic antioxidants in mediating the redox state of plant cells at different growth stages.

\section{Acknowledgement}

This work was supported by grants from the Research Fund of Atatürk University (Grant no: BAP-2009/233, Grant no: 2009/384) and The Scientific and Technological Research Council of Turkey (TUBITAK, grant no 2218).

\section{References}

Ahmad P, Sarwat M, Sharma S. Reactive oxygen species, antioxidants and signaling in plants. J Plant Biol 2008;51:167-73.

Aladjadjiyan A. Study of the influence of magnetic field on some biological characteristics of Zea mays. J Cent Eur Agric 2002;3:89-94.

Atici O, Nalbantoglu B. Antifreeze proteins in higher plants. Phytochemistry 2003;64:1187-96.

Belyavskaya NA. Biological effects due to weak magnetic field on plants. Adv Space Res 2004;34:1566-74.

Beers R, Sizer I. A spectrophotometric method for measuring the breakdown of hydrogen peroxide by catalase. J Biol Chem 1952;195:133-40.

Bradford M. A rapid and sensitive method for the quantitation of microgram quantities of protein utilizing the principle of protein-dye binding. Anal Biochem 1976;72:248-54.

Cakmak T, Atici O. Effects of putrescine and low temperature on the apoplastic antioxidant enzymes in the leaves of two wheat cultivars. Plant Soil Environ 2009;55:320-6.

Cakmak T, Dumlupinar R, Erdal S. Acceleration of germination and early growth of wheat and bean seedlings grown under various magnetic field and osmotic conditions. Bioelectromagnetics 2010a;31:120-9.

Cakmak T, Dumlupinar R, Erdal S. Chilling resistance of Phaseolus vulgaris and Brassica oleracea under a high-intensity electric field. Z Naturforsch C 2010b;65:380-6.

Clare D, Rabinowitch H, Fridovich I. Superoxide dismutase and chilling injury in Chlorella ellipsoidea. Arch Biochem Biophys 1984;231:158-63.

Costanzo E. The influence of electric field on the growth of soy seedlings. J Electrostat 2008;66:417-20.

Dat JF, Van Montagu M, Inze D, Van Breusegem F. Catalase-deficient tobacco plants: tools for in planta studies on the role of hydrogen peroxide. Redox Rep 2001;6:37-42.

De Pinto M, De Gara L. Changes in the ascorbate metabolism of apoplastic and symplastic spaces are associated with cell differentiation. J Exp Bot 2004;55:2559-69.

Dhindsa R, Plumbdhindsa P, Thorpe T. Leaf senescence-correlated with increased levels of membrane-permeability and lipid-peroxidation, and decreased levels of superoxide-dismutase and catalase. J Exp Bot 1981;32:93-101.

Foyer C, Halliwell B. Presence of glutathione and glutathione reductase in chloroplast: a proposed role in ascorbic acid metabolism. Planta 1976;133:21-5.

Foyer C, LopezDelgado H, Dat J, Scott I. Hydrogen peroxide- and glutathioneassociated mechanisms of acclimatory stress tolerance and signalling. Physiol Plantarum 1997;100:241-54.

Ghanati F, Morita A, Yokota H. Effects of aluminum on the growth of tea plant and activation of antioxidant system. Plant Soil 2005;276:133-41.

Griffiths DJ. Introduction to electrodynamics. 3rd ed. Prentice Hall; 1999. p. 265-266. ISBN 0-13-805326-X. OCLC 40251748.

Hajnorouzi A, Vaezzadeh M, Ghanati F, Jamnezhad H, Nahidian B. Growth promotion and a decrease of oxidative stress in maize seedlings by a combination of geomagnetic and weak electromagnetic fields. J Plant Physiol 2011;168:1123-8.
Hodges D, DeLong J, Forney C, Prange R. Improving the thiobarbituric acidreactive-substances assay for estimating lipid peroxidation in plant tissues containing anthocyanin and other interfering compounds. Planta 1999;207: 604-11.

Isobe S, Ishida N, Koizumi M, Kano H, Hazlewood CF. Effect of electric field on physical states of cell-associated water in germinating morning glory seeds observed by ${ }^{1} \mathrm{H}-\mathrm{NMR}$. Biochim Biophys Acta 1999;1426:17-31.

Kornberg A, Horecker B. Glucose-6-phosphate dehydrogenase. In: Colowick S, Kaplan N, editors. Methods in enzymology, vol. 1. New York, USA: Academic Press; 1955. p. 323-5.

Kukavica B, Mojovic M, Vučinić Z, Maksimović V, Takahama U, Jovanovic SV. Generation of hydroxyl radical in isolated pea root cell wall, and the role of cell wall-bound peroxidase, Mn-SOD and phenolics in their production. Plant Cell Physiol 2009;50(2):304-17.

McCann J, Dietrich F, Rafferty C, Martin AO. A critical review of the genotoxic potential of electric and magnetic fields. Mutat Res Rev Genet Toxicol 1993;297:61-95.

McKersie B, Chen Y, Debeus M, Bowley S, Bowler C, Inze D, et al. Superoxide dismutase enhances tolerance of freezing stress in transgenic alfalfa (Medicago sativa L.). Plant Physiol 1993;102:85.

Mittler R. Oxidative stress, antioxidants and stress tolerance. Trends Plant Sci 2002; 7:405-10.

Moon JD, Chung HS. Acceleration of germination of tomato seed by applying AC electric and magnetic fields. J Electrost 2000;48:103-14.

Nakano Y, Asada K. Hydrogen-peroxide is scavenged by ascorbate-specific peroxidase in spinach-chloroplasts. Plant Cell Physiol 1981;22:867-80.

Neamtu S, Morariu VV. Plant growth in experimental space flight field conditions. Roman J Biophys 2005;15:41-6.

Nechitailo G, Gordeev A. Effect of artificial electric fields on plants grown under microgravity conditions. Space Life Sci 2001;28:629-31.

Noctor G, Foyer C. A re-evaluation of the ATP: NADPH budget during C-3 photosynthesis: a contribution from nitrate assimilation and its associated respiratory activity? J Exp Bot 1998;49:1895-908.

Patykowski J, Urbanek $\mathrm{H}$. Activity of enzymes related to $\mathrm{H}_{2} \mathrm{O}_{2}$ generation and metabolism in leaf apoplastic fraction of tomato leaves infected with Botrytis cinerea. J Phytopathol 2003;151:153-61.

Phirke P, Kubde A, Umbarkar S. The influence of magnetic field on plant growth. Seed Sci Technol 1996;24:375-92.

Polle A, Otter T, Seifert F. Apoplastic peroxidases and lignification in needles of Norway spruce (Picea abies L.). Plant Physiol 1994;106:53-60.

Queval G, Noctor G. A plate reader method for the measurement of NAD, NADP, glutathione, and ascorbate in tissue extracts: application to redox profiling during Arabidopsis rosette development. Anal Biochem 2007;363:58-69.

Sahebjamei H, Abdolmaleki P, Ghanati F. Effects of magnetic field on the antioxidant enzyme activities of suspension-cultured tobacco cells. Bioelectromagnetics 2007;28:42-7.

Shabrangi A, Majd A. Effect of magnetic fields on growth and antioxidant systems in agricultural plants. In: Piers 2009 Beijing: Progress in Electromagnetics Research Symposium, Proceedings I and II; 2009. p. 1142-1147.

Somerville C, Ogren W. Isolation of photorespiration mutants in Arabidopsis thaliana. In: Edelman M, Hallick R, Chua N, editors. Methods in chloroplast biology. New York, USA: Elsevier Biomedical Press; 1982. p. 129-38.

Stange B, Rowland R, Rapley B, Podd J. ELF magnetic fields increase amino acid uptake into Vicia faba L. roots and alter ion movement across the plasma membrane. Bioelectromagnetics 2002;23:347-54

Tasgin E, Atici O, Nalbantoglu B, Popova L. Effects of salicylic acid and cold treatments on protein levels and on the activities of antioxidant enzymes in the apoplast of winter wheat leaves. Phytochemistry 2006;67:710-5.

Upadhyaya A, Sankhla D, Davis T, Sankhla N, Smith B. Effect of paclobutrazol on the activities of some enzymes of activated oxygen-metabolism and lipidperoxidation in senescing soybean leaves. J Plant Physiol 1985;121:453-61.

Vanacker H, Carver T, Foyer C. Pathogen-induced changes in the antioxidant status of the apoplast in barley leaves. Plant Physiol 1998;117:1103-14.

Vashisth A, Nagarajan S. Effect on germination and early growth characteristics in sunflower (Helianthus annuus) seeds exposed to static magnetic field. J Plant Physiol 2010;167:149-56.

Velikova V, Yordanov I, Edreva A. Oxidative stress and some antioxidant systems in acid rain-treated bean plants-protective role of exogenous polyamines. Plant Sci 2000;151:59-66.

Wang G, Huang J, Gao W, Lu J, Li J, Liao R, et al. The effect of high-voltage electrostatic field (HVEF) on aged rice (Oryza sativa L.) seeds vigor and lipid peroxidation of seedlings. J Electrostat 2009;67:759-64.

Wawrecki W, Zagorska-Marek B. Influence of a weak DC electric field on root meristem architecture. Ann Bot 2007;100:791-6.

Xue YJ, Tao L, Yang ZM. Aluminum-induced cell wall peroxidase activity and lignin synthesis are differentially regulated by jasmonate and nitric oxide. J Agric Food Chem 2008;56:9676-84.

Yazici I, Turkan I, Sekmen A, Demiral T. Salinity tolerance of purslane (Portulaca oleracea L.) is achieved by enhanced antioxidative system, lower level of lipid peroxidation and proline accumulation. Environ Exp Bot 2007;61:49-57. 